\title{
Intercropping organic field peas with barley, oats, and mustard improves weed control but has variable effects on grain yield and net returns
}

\author{
Will Bailey-Elkin, Michelle Carkner, and Martin H. Entz
}

\begin{abstract}
Interest in intercropping semi-leafless field peas (Pisum sativum L.) is increasing as a means of weed control in organic production. We evaluated field pea (cv. CDC Amarillo) grown alone or intercropped with three seeding rates of either barley (Hordeum vulgare L.), mustard (Brassica juncea L.), or oat (Avena sativa L.). A full seeding rate of field pea was used in each instance, resulting in an additive intercropping design. Each crop combination was conducted in a separate experiment, three times over two years (2019 and 2020) in Carman, MB. Measurements included crop and weed biomass production, grain yield and quality, and net return. Intercrops reduced weed biomass at maturity from $17 \%$ to $44 \%$ with barley and oat being more suppressive than mustard. Intercrops also reduced field pea yield from $6 \%$ to $26 \%$, but increased field pea seed mass. Barley at the high seeding rate provided the most weed suppression per unit of field pea yield loss $(2.62 \mathrm{~kg}$ of weed suppression per $\mathrm{kg}$ of field pea yield loss) compared with oat (1.29) and mustard (0.87). Barley and mustard intercrops decreased net return compared with monoculture field pea. Under low weed pressure (1150 $\mathrm{kg} \cdot \mathrm{ha}^{-1}$ weed biomass at maturity) and earlier seeding, oat intercrops reduced net return. However, under weedy conditions $\left(2649 \mathrm{~kg} \cdot \mathrm{ha}^{-1}\right)$ and later seeding, field pea-oat intercrops significantly increased net return. In conclusion, while all three intercrop mixtures reduced weed biomass, reductions in field pea yields were observed, and net return benefits were observed only in certain circumstances.
\end{abstract}

Key words: pea intercropping, organic pea production, integrated weed management.

Résumé : L'agriculture biologique s'intéresse de plus en plus à la culture intercalaire du pois de plein champ semi-aphylle (Pisum sativum L.) pour lutter contre les mauvaises herbes. Les auteurs ont évalué la monoculture du pois (cv. CDC Amarillo) ou sa culture intercalaire avec de l'orge (Hordeum vulgare L.), de la moutarde (Brassica juncea L.) ou de l'avoine (Avena sativa L.) à trois densités de semis. Le pois a été semé à sa densité maximale dans les trois cas, de manière à obtenir un effet additif. Chaque combinaison agricole a fait l'objet d'une expérience distincte, à trois reprises en deux ans (2019 et 2020), à Carman (Manitoba). Les auteurs ont mesuré la biomasse de la culture et des adventices, le rendement grainier, la qualité des graines et le revenu net. La culture intercalaire réduit la biomasse de mauvaises herbes à maturité de 17 à $44 \%$, avec une plus grande suppression pour l'orge et l'avoine que pour la moutarde. La culture intercalaire diminue aussi le rendement du pois de 6 à $26 \%$, mais augmente la masse des graines. À la densité des semis la plus élevée, l'orge enregistre une meilleure suppression des mauvaises herbes pour chaque unité de rendement du pois perdue (2,62 kg d'adventices supprimées par kilo de rendement en moins du pois) que l'avoine $(1,29)$ et la moutarde $(0,87)$. Les cultures intercalaires d'orge et de moutarde enregistrent un revenu net inférieur à celui de la monoculture du pois. Quand les adventices sont peu nombreuses (biomasse de $1150 \mathrm{~kg}$ par hectare à maturité) et qu'on sème plus tôt, la culture intercalaire d'avoine diminue le revenu net. Cependant, avec des adventices plus abondantes ( $2649 \mathrm{~kg}$ par hectare) et des semis plus tardifs, la culture intercalaire du pois et de l'avoine accroît sensiblement le revenu net. En conclusion, bien que les trois combinaisons de culture intercalaire réduisent la biomasse de mauvaises herbes, on note une baisse du rendement du pois de plein champ et le revenu net n'augmente que dans certaines circonstances. [Traduit par la Rédaction]

Mots-clés : culture intercalaire du pois, culture biologique du pois, lutte intégrée contre les mauvaises herbes.

Received 4 August 2021. Accepted 22 October 2021.

W. Bailey-Elkin, M. Carkner, and M.H. Entz. Department of Plant Science, University of Manitoba, Winnipeg, MB, Canada, R3T 2 N2. Corresponding author: Martin H. Entz (email: M.Entz@umanitoba.ca).

(C) 2021 The Author(s). This work is licensed under a Creative Commons Attribution 4.0 International License (CC BY 4.0), which permits unrestricted use, distribution, and reproduction in any medium, provided the original author(s) and source are credited. 


\section{Introduction}

From 2015 to 2018 there has been a $40 \%$ increase in organic field pea (Pisum sativum L.) production in Canada, reaching over 52600 hectares (Canadian Organic Trade Association 2018). Predictions are that demand for organic field peas will increase in the coming decades (Manitoba Pulse \& Soybean Growers 2019). Adding field peas to an organic rotation can increase crop diversity, disrupt the lifecycles of disease and weed communities (Anderson 2005; Ma 2016), and enrich the soil with nitrogen $(\mathrm{N})$ through atmospheric $\mathrm{N}$ fixation (Beckie and Brandt 1997).

Benefits of intercropping often include weed and disease suppression, reduced lodging, efficient resource use, and soil erosion protection (Wall et al. 1991; Pridham 2006; Corre-Hellou et al. 2011; PodgórskaLesiak and Sobkowicz 2013). In addition, intercropping can lead to increased per hectare yields and gross returns, as well as reduced risk of total crop failure (Anil et al. 1998; Martin-Guay et al. 2018). In low-N soils, intercropping can increase $\mathrm{N}_{2}$ fixation in the legume component (Hauggaard-Nielsen et al. 2009; Chapagain and Riseman 2014).

Intercropping has emerged as a unique way to manage risks associated with organic production. Legumes such as field peas are known to experience unstable yields and lack the ability to tolerate variable environmental conditions such as high temperatures at flowering (Watson et al. 2017; Jiang et al. 2019). Intercropping peas with companion crops allow the benefits of intercropping to be captured (ie., weed and disease suppression, over-yielding, and less lodging) (Langat 1992; Pridham and Entz 2008; Corre-Hellou et al. 2011). Langat (1992) observed greater field pea seed mass when grown in intercrops.

Semi-leafless field peas are especially susceptible to weed competition due to late canopy closure (Spies et al. 2010). This was demonstrated in Alberta where $67 \%$ of the surveyed field pea fields suffered significant yield losses due to weeds, with field peas suffering more than barley or canola (Brassica napus L.) (Harker 2001). Because barley and oats are competitive with early season weeds due to rapid canopy development (Satorre and Snaydon 1992; Beres et al. 2010; Bouhaouel et al. 2015) and production of allelopathic compounds (Bouhaouel et al. 2015), these crops are recommended as companion crops for field peas (Wallace and Canadian Organic Growers 2001). Corre-Hellou et al. (2011) found that field pea-barley intercrops established in an additive design reduced $(P<0.05)$ weed biomass from 985 to $279 \mathrm{~kg} \cdot \mathrm{ha}^{-1}$, compared with a field pea monoculture. Brassicas such as mustard are less competitive than barley or oats, but their rapid growth and high level of biomass production can suppress weeds (Blackshaw et al. 2002; Beckie et al. 2008). In a review of the literature 30 years ago, Liebman and Dyck (1993) found that weed biomass was reduced in $90 \%$ of cases when a main crop was intercropped with a "smother crop"; more recent examples are given in Blackshaw et al. (2002).

Field pea intercrops with wheat (Triticum aestivum L.), oats, barley, and mustard has been previously studied (Pridham and Entz 2008; Bedoussac and Justes 2010; Arlauskiene et al. 2014). However, past studies have mainly used peas as a companion crop (Bedoussac and Justes 2010; Monti et al. 2016), often to add N to the cropping system (Patra et al. 1986; Izaurralde et al. 1992). Such "replacement designs" have included two crop species planted in ratios of $50: 50,66: 33$, or 70:25, equating to a total plant density of $100 \%$ (Nelson et al. 2012) or in innovative spatial arrangements (Chapagain and Riseman 2014). Due to the low seeding rates used, and the lack of field pea competitiveness with weeds, 50:50 ratio mixtures of field pea intercrops can result in suboptimal field pea yields and poor weed control (Pridham and Entz 2008; Nelson et al. 2012; Pelzer et al. 2016).The present study considered an additive mixture, where a high density of field peas was intercropped with various seeding rates of companion crops. One important objective in the research was whether the additive mixtures (with field pea as main crop) would provide weed suppression without compromising field pea grain or economic yield. Working with finger millet (Eleusine coracana (L.) Gaertn.) - haricot (Phaseolus vulgaris L.) in an additive intercrop design, Bitew et al. (2020) observed a $2 \%$ to $5 \%$ finger millet yield penalty. On the other hand, Saucke and Ackermann (2006) observed no yield penalty in additive field pea-false flax (Camelina sativa (L.) Crantz) intercrops.

We were also interested in knowing how different seeding rates would affect the balance between weed suppression and field pea seed yield. Increasing the seeding rate of barley and oats is known to increase grain yield and the competitiveness with other plants (Blackshaw et al. 2002; Mason et al. 2007; Beres et al. 2010). However, in grain intercropping, as one crop species density is increased over another with similar environmental niche requirements, the level of interspecific competition increases, resulting in reduced biomass and grain yields of the crop species that is being outcompeted (Vandermeer 1992; Pelzer et al. 2016). Hence, our second objective was to compare field pea yield and weed suppression at standard field pea plant populations, but increasing populations of the companion crops, barley, oat and mustard. We hypothesized that field pea intercrops would reduce weed biomass and field pea grain yields in comparison to the pea monocrop control and wanted to investigate the extent of these effects. In addition, we hypothesized that the additional harvest of the non-field pea grain in the field pea intercrops may compensate for any reductions in field pea grain yield, leading to greater net returns than the pea monocrop control. By investigating different field 
pea intercrop companion crops and seeding rates this study aimed to further understand their effect on weed suppression, crop and weed biomass productivity, grain yield and grain quality, and profitability.

\section{Materials and Methods}

In 2019 and 2020 three separate semi-leafless yellow field pea intercrop experiments (yellow field pea-barley, yellow field pea-oat, and yellow field pea-mustard) were completed at the Ian N. Morrison Research Farm in Carman, MB, Canada $\left(49^{\circ} 29^{\prime} 56^{\prime \prime} \mathrm{N}, 98^{\circ} 1^{\prime} 29^{\prime \prime} \mathrm{W}\right)$. Two siteyears were conducted in 2020; conditions were varied by staggering the seeding dates. In 2019 the experiments were seeded on 10 May (Carman 2019). In 2020 the same experiments were seeded on 7 May (Carman 2020a) and 21 May (Carman 2020b). Each experiment was a randomized complete block design replicated four times, with 2 by $10 \mathrm{~m}$ plots. At each site-year the three separate field pea intercrop experiments (field pea-barley, field pea-oat, and field pea-mustard) were planted side-by-side in field sections separated by a 2-m border. Each site year had natural weed populations that were uniform across the experiment.

The 2019 experiments were preceded by an oat grain crop; $2020 a$ experiments were preceded by a rye grain crop, and $2020 \mathrm{~b}$ experiments were preceded by a wheat grain crop. A small number of volunteer oats from previous years were hand weeded before heading. All areas were managed organically since 2004 . Fields were tilled two times ( $6 \mathrm{~cm}$ deep) immediately before seeding. Field peas and their associated companion crops were seeded together in the same rows at the same depth of $2-5 \mathrm{~cm}$ using a cone seeder with double disc openers, with $15 \mathrm{~cm}$ row spacing (Fabro Enterprises Ltd., Swift Current, SK, Canada). Entire plots were harvested using a Wintersteiger plot combine (Wintersteiger Ag., Ried im Innkreis, Austria).

Field peas were planted in both monoculture and additive intercrop plant stands. Field peas exhibited 98\% germination in 2019 and 2020 and seeding rates were adjusted for germination test results and a $10 \%$ mortality rate. Field peas (cv. CDC Amarillo) were sown at the appropriate rate to achieve a target plant density of 120 plants $\mathrm{m}^{-2}$. Field peas were inoculated with a liquid-based rhizobium (Rhizobium leguminosarum (Frank) Ramírez-Bahena) inoculant at $35 \mathrm{~mL}$ per $11 \mathrm{~kg}$ of seed (Nodulator XL, BASF, Ludwigshafen, Germany). Mustard exhibited 96\% germination in 2019 and 98\% germination in 2020 . Barley and oats exhibited $98 \%$ germination in 2019 and 95\% germination in 2020. Mustard, barley, and oat seeding rates were adjusted for germination test results and a $10 \%$ mortality rate. The non-field pea companion crop species were seeded to low (approximately $10 \%$ ), medium (approximately $25 \%$ ), or high percentages (approximately 50\%) of their recommended monoculture target plant densities: low barley, 40 plants $\cdot \mathrm{m}^{-2}$, medium barley, 75 plants $\cdot \mathrm{m}^{-2}$, high
Table 1. Soil nutrient status and $\mathrm{pH}$ of three site-years for three pea intercrop experiments (pea-barley, pea-mustard, and pea-oat) in 2019 and 2020, located in Carman MB, Canada.

\begin{tabular}{llllll}
\hline Site-year & $\mathrm{N}^{a}$ & $\mathrm{P}^{b}$ & $\mathrm{~K}$ & $\mathrm{~S}$ & $\mathrm{pH}^{c}$ \\
\cline { 2 - 5 } & \multicolumn{5}{c}{$\mathrm{ppm}$} \\
Carman 2019 $(0-60 \mathrm{~cm})$ & 26 & 10 & 205 & 25 & 6.0 \\
Carman 2020a $(0-30 \mathrm{~cm})$ & 12.5 & 10 & 246 & 13 & 5.9 \\
Carman 2020b $(0-30 \mathrm{~cm})$ & 13 & 11 & 368 & 8 & 6.1 \\
\hline
\end{tabular}

Note: 2020 soil nutrient status measurements were taken at a depth of 0-30 cm while the 2019 soil analysis measurements were taken at a depth of 0-60 cm. Analysis completed by Agvise Laboratories Ltd.

${ }^{a} \mathrm{~N}=$ ppm in nitrate.

${ }^{b} \mathrm{P}$ measured using Olsen phosphorous analysis method.

${ }^{c} \mathrm{pH}$ measurements were taken at the $0-15 \mathrm{~cm}$ soil depth for all site-years.

barley, 150 plants $\cdot \mathrm{m}^{-2}$; low mustard, 43 plants $\cdot \mathrm{m}^{-2}$, medium mustard, 87 plants $\cdot \mathrm{m}^{-2}$, high mustard, 131 plants $\cdot \mathrm{m}^{-2}$; low oat, 48 plants $\cdot \mathrm{m}^{-2}$, medium oat, 80 plants $\mathrm{m}^{-2}$, and high oat, 160 plants $\mathrm{m}^{-2}$. In 2019 , due to a mechanical error, barley and oats were seeded at twice the target plant densities. This resulted in a doubling of barley and oat plant density in the Carman 2019 experiments compared with the other two site-years (Carman $2020 a$ and 2020b).

Climatic data was obtained from the Manitoba AgWeather Program and Environment Canada, Manitoba Station. The soil in Carman is orthic black Chernozem of the Hochfeld series with a very fine sandy loam texture and an average $\mathrm{pH}$ of 6.6-7.3 (neutral), with a medium organic matter content (Mills and Haluschuk 1993; Manitoba Agriculture and Resource Development 2020). Soil samples were taken at random in the spring before the growing season using a Dutch auger at a depth of 0-60 cm in 2019 and $0-30 \mathrm{~cm}$ in 2020 . All siteyears had residual soil $\mathrm{N}$ levels below the recommended 30 ppm; 26 ppm in Carman 2019 (0-60 cm depth), and 12.5 to 13 for Carman 2020 (0-30 cm depth) sites (Table 1). Across all site-years phosphorous (P) levels were moderate (10-11 ppm range), while potassium levels were above $200 \mathrm{ppm}$ (205 to $368 \mathrm{ppm}$ range) (Table 1).

Crop density was measured by counting two randomly selected one-metre sections of two crop rows in each plot, after full crop emergence. Maturity biomass samples were taken from two $0.25 \mathrm{~m}^{-2}$ quadrats, in each plot, when crops had reached physiological maturity. Biomass samples were separated into field pea, non-field pea companion crop and weed biomass components. Separated samples were dried in an oven at $65{ }^{\circ} \mathrm{C}$ for $48 \mathrm{~h}$ and weights were taken. Thousand kernel weights (TKW) were measured using a seed counter and scale. Field pea protein percentage on a dry matter basis was measured using a Perten Inframatic 9500 near-infrared 
Table 2. Grain prices and production costs used for economic analysis of three pea intercrop experiments (pea-barley, pea-oat, and pea-mustard) in 2019 and 2020, in Carman MB, Canada.

\begin{tabular}{|c|c|}
\hline \multicolumn{2}{|l|}{ Seed costs } \\
\hline $\begin{array}{l}\text { Pea }+ \text { inoculant }^{a} \\
\text { Barley }^{a} \\
\text { Oat }^{a} \\
\text { Mustard }^{b}\end{array}$ & $\begin{array}{l}\$ 0.61 \mathrm{~kg}^{-1} \\
\$ 0.51 \mathrm{~kg}^{-1} \\
\$ 0.59 \mathrm{~kg}^{-1} \\
\$ 9.64 \mathrm{~kg}^{-1}\end{array}$ \\
\hline \multicolumn{2}{|l|}{ Other costs } \\
\hline $\begin{array}{l}\text { Seed separation cost }{ }^{c} \\
\text { Operating costs minus seed cost, } \\
\text { separation cost, and crop insurance } \\
\text { Fixed costs } \\
\text { Labour }^{d}\end{array}$ & $\begin{array}{l}\$ 0.02 \mathrm{~kg}^{-1} \\
\$ 511.89 \mathrm{ha}^{-1} \\
\$ 337.48 \mathrm{ha}^{-1} \\
\$ 177.84 \mathrm{ha}^{-1}\end{array}$ \\
\hline \multicolumn{2}{|l|}{ Grain market prices } \\
\hline $\begin{array}{l}\text { Peas }^{e} \\
\text { Barley }^{e} \\
\text { Oat }^{e} \\
\text { Mustard }^{e}\end{array}$ & $\begin{array}{l}\$ 0.53 \mathrm{~kg}^{-1} \\
\$ 0.36 \mathrm{~kg}^{-1} \\
\$ 0.49 \mathrm{~kg}^{-1} \\
\$ 1.78 \mathrm{~kg}^{-1}\end{array}$ \\
\hline $\begin{array}{l}{ }^{a} \text { Estimated seed cost adapted from ( } \mathrm{Pr} \\
\text { Manitoba 2020). } \\
{ }^{b} \text { Estimated seed cost adapted from (Go } \\
\text { Saskatchewan 2020). } \\
{ }^{c} \text { Average separation cost obtained fror } \\
\text { intercropping survey (Bailey-Elkin 2021). } \\
{ }^{d} \text { Production costs adapted from (Provir } \\
2020 \text { ). } \\
{ }^{e} \text { Organic grain market prices adapted } \\
\text { (OrganicBiz 2020). }\end{array}$ & $\begin{array}{l}\text { ernment of } \\
\text { pea } \\
\text { e of Manitoba }\end{array}$ \\
\hline
\end{tabular}

grain analyzer (PerkinElmer, Massachusetts, USA). Field pea intercrop grain yields were separated using a dockage sorter and spiral gravity separator.

Net returns were calculated by using organic production costs that were determined by reviewing a pea intercropping survey (Bailey-Elkin 2021), and by referencing Government of Saskatchewan (2020); Manitoba Agricultural Services Corporation (2020); Province of Manitoba (2020); and Saskatchewan Crop Insurance Corporation (2020). In the economic analysis, the only additional cost of field pea intercropping compared with the field pea monoculture was the cost of non-field pea seed, the grain separation cost, and crop insurance (Table 2). Net returns were defined as the gross revenue minus total costs (fixed costs + operating costs + labour).

\section{Statistical analysis}

Using PROC Mixed procedure in SAS version 9.4 (SAS Institute, Inc. 2020), the Analysis of Variance Method (ANOVA) was used to compare treatment differences within each experiment on the following measurements: plant population density, biomass at maturity, grain yield, and net returns. Site-year was a combination of site and/or year, resulting in three separate site-years
(Carman 2019, Carman 2020a, and Carman 2020b). Site-years were combined for the analysis and when site-year $\times$ treatment interactions were detected, data were analyzed separately. No significant site-year by treatment interaction was observed for plant population density, even though a higher seeding rate for companion crops was used in 2019. This supported a combined site-years analysis. Treatments, site-years, and site-year $\times$ treatment were considered fixed effects and replicates nested within site-years were considered random effects. The PROC Univariate procedure was used to test for the normality of residuals. When normality was not met, $\log$ transformations were used. Log transformed data were back transformed when presented in tables and figures. If homogeneity of the residuals was not met upon visual inspection of the residual panel of the predicted values vs. the residual values, a repeated/ group statement (group $=$ treatment, group $=$ site-year, group $=$ site-year $\times$ treatment) was used to account for heterogeneity of variance. Following the visual inspection, the best fit was identified by using the lowest AIC values. Means were separated using the lsmeans statement and considered significant at $P<0.05$ using the Tukey test.

\section{Results and Discussion \\ Climate}

The 2019 and 2020 growing season mean temperatures were the same $\left(13.9{ }^{\circ} \mathrm{C}\right)$ at $98 \%$ of the long-term mean temperature (Table 3). Growing season precipitation in 2019 and 2020 was $64 \%$ and $61 \%$ of the long-term precipitation, respectively (Table 3), resulting in drier than average conditions.

\section{Weed populations}

The Carman 2020a site-year weed community was dominated by common lamb's quarter (Chenopodium album L.), smart weed (Polygonum pensylvanicum L.), wild buckwheat [Fallopia convolvulus (L.) Á. Löve], and Canada thistle (Cirsium arvense L.). Carman 2019 and Carman $2020 b$ were dominated by green foxtail (Setaria viridis L.). Weed biomass at maturity was similar between Carman 2019 and 2020a (1216 and $1176 \mathrm{~kg} \cdot \mathrm{ha}^{-1}$, respectively) but higher at Carman $2020 \mathrm{~b}\left(2412 \mathrm{~kg} \cdot \mathrm{ha}^{-1}\right)$. These biomass levels may be considered above-average when compared with 41 organic green manure fields across southern Manitoba and eastern Saskatchewan (average weed biomass $675 \mathrm{~kg} \cdot \mathrm{ha}^{-1}$, range 0 to $3266 \mathrm{~kg} \cdot \mathrm{ha}^{-1}$ ) (Thiessen Martens et al. 2019), or organic field experiments in Alberta (weed biomass 25 to $868 \mathrm{~kg} \cdot \mathrm{ha}^{-1}$ ) (Nelson et al. 2012).

\section{Plant population density}

Baird et al. (2009) reported an optimal target plant density for organic field peas of 120 plants $\cdot \mathrm{m}^{-2}$. In the present study, field pea monoculture ranged from $73 \%$ to $89 \%$ of this target plant density for barley 
Table 3. Mean monthly temperature $\left({ }^{\circ} \mathrm{C}\right)$ and precipitation $(\mathrm{mm})$ for September 2018 to August 2020 in Carman MB, Canada.

\begin{tabular}{|c|c|c|c|c|c|c|c|c|c|c|c|c|}
\hline \multirow[b]{2}{*}{ Location } & \multicolumn{2}{|c|}{ April } & \multicolumn{2}{|c|}{ May } & \multicolumn{2}{|c|}{ June } & \multicolumn{2}{|l|}{ July } & \multicolumn{2}{|c|}{ August } & \multicolumn{2}{|c|}{$\begin{array}{l}\text { Growing } \\
\text { Season }^{a}\end{array}$} \\
\hline & $T^{b}$ & $P$ & $\mathrm{~T}$ & $P$ & $\mathrm{~T}$ & $P$ & $\mathrm{~T}$ & $P$ & $T$ & $P$ & $T$ & $P$ \\
\hline Carman 2019 & 4.8 & 17 & 9.6 & 37 & 17.3 & 37 & 19.6 & 57 & 18.1 & 61 & 13.9 & 209 \\
\hline Carman 2020 & 1.6 & 24 & 10.7 & 26 & 18.3 & 70 & 20.2 & 54 & 18.7 & 24 & 13.9 & 198 \\
\hline 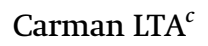 & 4.5 & 44 & 11.6 & 60 & 17.2 & 78 & 19.4 & 76 & 18.5 & 67 & 14.2 & 325 \\
\hline
\end{tabular}

${ }^{a}$ Total precipitation and average temperature over the growing season (April to end of August).

${ }^{b}$ Temperature $(T)$; precipitation $(P)$.

${ }^{c}$ Long term average (1981-2010) for Carman, MB (Environment Canada).

Table 4. Mean crop establishment of three pea intercrop (IC) experiments (pea-barley, pea-oat, and peamustard), averaged across three site-years in 2019 and 2020, in Carman MB, Canada.

\begin{tabular}{|c|c|c|c|c|c|c|}
\hline \multicolumn{7}{|l|}{ Mean crop establishment } \\
\hline & \multicolumn{6}{|c|}{ Plants $\mathrm{m}^{-2}$} \\
\hline & \multicolumn{2}{|c|}{ Pea-Barley } & \multicolumn{2}{|l|}{ Pea-Oat } & \multicolumn{2}{|c|}{ Pea-Mustard } \\
\hline & $\begin{array}{l}\text { Pea } \\
\text { density }\end{array}$ & $\begin{array}{l}\text { Barley } \\
\text { density }\end{array}$ & $\begin{array}{l}\text { Pea } \\
\text { density }\end{array}$ & $\begin{array}{l}\text { Oat } \\
\text { density }\end{array}$ & $\begin{array}{l}\text { Pea } \\
\text { density }\end{array}$ & $\begin{array}{l}\text { Mustard } \\
\text { density }\end{array}$ \\
\hline \multicolumn{7}{|l|}{ Site-year } \\
\hline Carman 2019 & $105 a$ & $119 a$ & $116 a$ & $177 \mathrm{a}$ & $122 \mathrm{a}$ & $47 a b$ \\
\hline Carman $2020 a$ & $87 b$ & $56 b$ & $91 b$ & $60 c$ & $92 b$ & $38 b$ \\
\hline Carman 2020b & $91 \mathrm{ab}$ & $74 \mathrm{~b}$ & $92 b$ & $78 b$ & $85 b$ & $54 a$ \\
\hline \multicolumn{7}{|l|}{ Treatment } \\
\hline Pea monocrop & $101 \mathrm{a}$ & - & $103 a$ & - & $111 a$ & - \\
\hline IC low seed rate & $86 a$ & $47 c$ & $99 a$ & $57 c$ & $94 b$ & $25 c$ \\
\hline IC medium seed rate & $99 a$ & $75 b$ & $92 a$ & $94 b$ & $95 a b$ & $43 b$ \\
\hline IC high seed rate & $92 a$ & 139a & $104 a$ & $163 a$ & $98 \mathrm{ab}$ & $74 a$ \\
\hline Site-year effect & 0.0230 & 0.0151 & 0.0006 & $<0.0001$ & $<0.0001$ & 0.0215 \\
\hline Treatment effect & 0.0757 & $<0.0001$ & 0.1584 & $<0.0001$ & 0.0372 & $<0.0001$ \\
\hline Site-year $\times$ treatment Interaction & 0.7111 & 0.5223 & 0.5816 & 0.0638 & 0.1198 & 0.2582 \\
\hline
\end{tabular}

Note: Means with different letters in the same column are significantly different (Tukey's HSD, $P<0.05$ ).

experiments, $76 \%$ to $97 \%$ for oat experiments and $71 \%$ to $102 \%$ for mustard experiments (Table 4). It is interesting to note that field pea plant density was greater in 2019 than 2020. Lower field pea plant emergence in 2020 may have been due to wet conditions during tillage in 2020 , resulting in a course seedbed due to soil clods on the soil surface. Surprisingly, field pea plant density was mostly unaffected $(P>0.05)$ by companion seeding rate, even though seeding rate increased the population density of the companion crops (Table 4). Similar results were observed for false flax intercropped with field pea (Saucke and Ackermann 2006). Therefore, any niche overlap for resources was not strong enough to reduce pea establishment. The lack of any significant intercrop treatment by site-year interaction for either field pea or companion crop plant density (Table 4) indicated that effects of companion crop seeding rates were consistent across the different environments, and that the higher seeding rate used in 2019 did not produce a different trend in field pea plant population results compared with the 2020 experiments.

\section{Maturity crop and weed biomass}

Field pea biomass at maturity ranged from 3007 to $4198 \mathrm{~kg} \cdot \mathrm{ha}^{-1}$ (Table 5); similar to biomass values reported for organic (Baird et al. 2009) and conventional (Borstlap and Entz 1994) field pea production. The early seeded site-year (Carman 2020a) produced significantly more pea biomass for all crops than the later seeded Carman $2020 b$ or Carman 2019. Early seeding is known to favour biomass accumulation in cool season crops such as peas and barley (Juskiw and Helm 2003; Chen et al. 2006). Low soil $\mathrm{N}$ status at Carman 2020a (Table 1) may also have been a contributing factor. Field pea $\mathrm{N}$ use efficiency was shown to be higher in intercrops than monocultures (HauggaardNielsen et al. 2009; Bedoussac and Justes 2010). 
Table 5. Mean maturity biomass of three pea intercrop (IC) experiments (pea-barley, pea-oat, and pea-mustard), averaged across three site-years in 2019 and 2020 , Carman MB, Canada.

\begin{tabular}{|c|c|c|c|c|c|c|c|c|c|c|c|c|}
\hline \multicolumn{13}{|c|}{ Mean maturity biomass $\left(\mathrm{kg} \cdot \mathrm{ha}^{-1}\right)$} \\
\hline & \multicolumn{4}{|c|}{ Pea-Barley } & \multicolumn{4}{|l|}{ Pea-Oat } & \multicolumn{4}{|c|}{ Pea-Mustard } \\
\hline & Pea & $\mathrm{CC}$ & TC & Weed & Pea & $\mathrm{CC}$ & TC & Weed & Pea & $\mathrm{CC}$ & TC & Weed \\
\hline \multicolumn{13}{|l|}{ Site-year } \\
\hline Carman 2019 & $2959 b^{a}$ & $1520 \mathrm{a}$ & $4268 \mathrm{~b}$ & 1197b & 2962b & $2164 a$ & $4727 a$ & $1150 \mathrm{~b}$ & $3528 \mathrm{~b}$ & $758 a$ & $4201 \mathrm{~b}$ & $1302 b$ \\
\hline Carman 2020a & $5658 \mathrm{a}$ & $304 \mathrm{~b}$ & $5924 a$ & $1069 \mathrm{~b}$ & $5320 \mathrm{a}$ & $458 \mathrm{c}$ & 5731a & $1232 \mathrm{~b}$ & $5138 a$ & $341 \mathrm{~b}$ & $5440 \mathrm{a}$ & $1228 \mathrm{~b}$ \\
\hline Carman 2020b & $2504 \mathrm{~b}$ & $574 \mathrm{~b}$ & 3010b & $2286 a$ & $2287 \mathrm{~b}$ & 973b & $3098 \mathrm{~b}$ & $2649 a$ & $2260 c$ & $361 \mathrm{ab}$ & $2568 c$ & 2310a \\
\hline \multicolumn{13}{|l|}{ Treatment } \\
\hline Pea monocrop & $4198 a$ & - & $4198 a$ & $1952 a$ & $3704 a b$ & - & $3704 b$ & $2085 a$ & 4156a & - & $4156 a$ & $1804 a$ \\
\hline IC low seed rate & 3983ab & $373 b$ & $4545 a$ & $1544 a b$ & $3772 a$ & $715 \mathrm{~b}$ & $4796 a$ & 1753ab & $3740 \mathrm{ab}$ & $277 \mathrm{~b}$ & 4119a & $1680 \mathrm{ab}$ \\
\hline IC medium seed rate & $3481 \mathrm{ab}$ & $679 a$ & $4434 a$ & $1261 b c$ & $3609 a b$ & $886 \mathrm{~b}$ & $4685 a$ & $1549 b$ & $3542 \mathrm{ab}$ & $479 a$ & $4052 a$ & $1472 b$ \\
\hline IC high seed rate & $3165 b$ & $1009 a$ & $4426 a$ & $1092 c$ & $3007 \mathrm{~b}$ & $1489 a$ & $4889 a$ & $1322 \mathrm{c}$ & $3130 \mathrm{~b}$ & 682a & $3951 a$ & $1498 \mathrm{~b}$ \\
\hline Site-year effect & $<0.0001$ & 0.0029 & 0.0011 & 0.0023 & $<0.0001$ & 0.0008 & 0.0002 & $<0.0001$ & 0.0003 & 0.0335 & 0.0003 & $<0.0001$ \\
\hline Treatment effect & 0.0184 & 0.0002 & 0.7658 & $<0.0001$ & 0.0226 & 0.0003 & 0.0003 & 0.0002 & 0.0277 & $<0.0001$ & 0.9315 & 0.0091 \\
\hline $\begin{array}{l}\text { Site-year } \times \text { treatment } \\
\text { interaction }\end{array}$ & 0.6055 & 0.0753 & 0.7944 & 0.0968 & 0.0314 & 0.3606 & 0.0731 & 0.1260 & 0.6810 & 0.0236 & 0.9766 & 0.0358 \\
\hline
\end{tabular}

Note: Means with different letters in the same column are significantly different (Tukey's HSD, $P<0.05$ ). Abbreviations: CC, companion crop biomass; TC, total crop biomass. 
Fig. 1. Pea biomass at physiological maturity (A) and net returns (D) of pea-oat intercrop experiment. Pea grain yields of peabarley (B) and pea-mustard (C) intercrop experiments. Error bars represent standard errors of the least-squares means. Treatments are clustered by site-year. Means with different letters are significantly different (Tukey’s HSD, $P<0.05$ ).

A

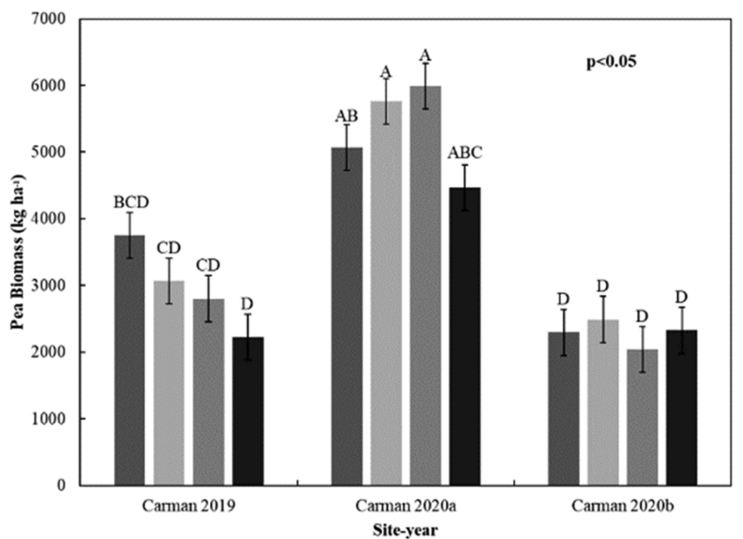

C

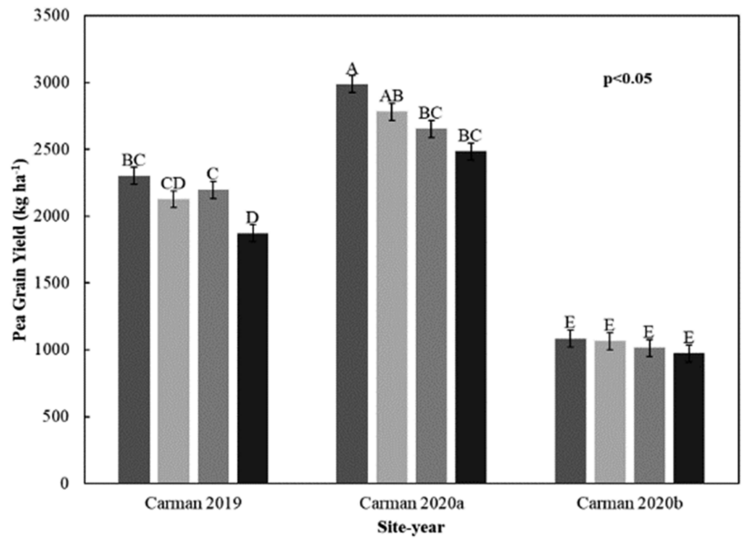

B

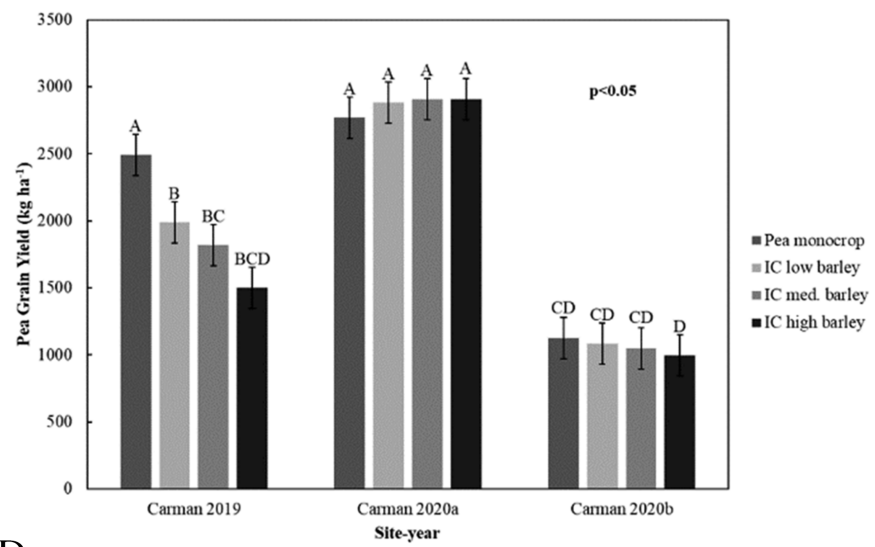

$\mathrm{D}$

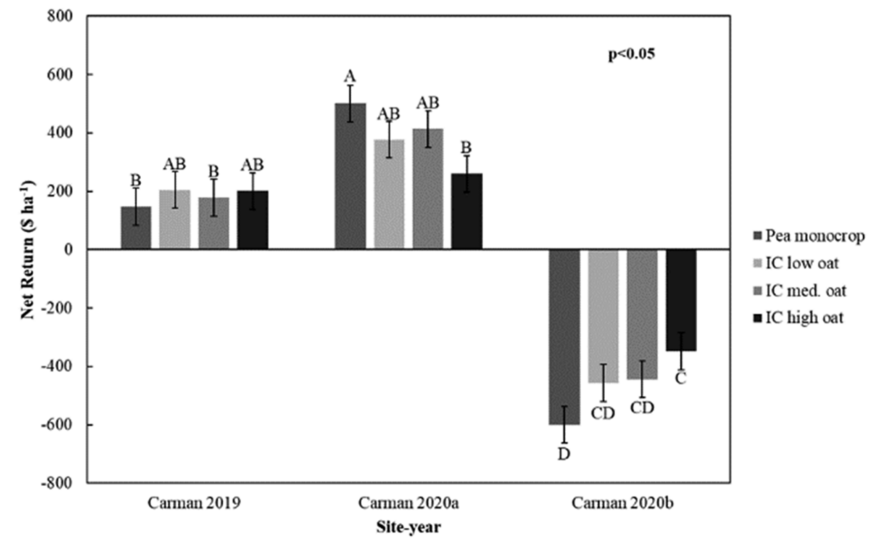

Previous research has shown that intercrops often (Langat 1992), though not always (Gliessman 1990) decrease growth of the main crop. In the present study, only the highest seeding rates of barley and mustard significantly reduced field pea biomass compared with the monoculture or the lower companion crop seeding rates (Table 5). No significant interactions between siteyear and barley or mustard seeding rate were observed indicating similar trends of these intercrops on field pea biomass across the range of growing conditions. However, a significant site-year by intercrop seeding rate interaction was observed for oat. At Carman 2019, oat intercropping resulted in lower field pea biomass levels than monoculture (Fig. 1A) while at Carman 2020a and $2020 b$, field pea biomass was not significantly affected by oat at any seeding rate. Grimmer and Masiunas (2005) found that the presence of oat in a pea-oat cover crop study inhibited pea germination, due to the presence of allelopathic chemicals from oat. Although there was no effect of intercropping on field pea plant density in our study, the reduction in field pea biomass in 2019 only, may have been due to the overseeding of oat, resulting in a greater presence of allelopathic chemicals, thereby reducing field pea biomass.

Intercrops contributed $8 \%, 15 \%$, and $23 \%$ to the total crop biomass for the low, medium, and high seeding rates for barley, $14 \%, 19 \%$, and $30 \%$ for oat, and $7 \%, 11 \%$, and $17 \%$ for mustard, respectively (Table 5). For all three companion crops, the highest seeding rates resulted in statistically greater companion crop biomass at maturity than the lowest seeding rate (Table 5). However, total crop biomass (field pea and companion crop) was increased only with oats, where intercropping increased total crop biomass compared with the field pea monocrop (Table 5). For barley and mustard, total crop biomass was similar to the field pea monoculture. Therefore, within a static field pea population regime, increasing the seeding rate of the non-field pea crop resulted in more total crop biomass at harvest only for oat. Others have also observed that an additive field pea intercropping system increases above ground net primary productivity over field pea monocrops (Corre-Hellou et al. 2011) and the overyielding with oat here helps explain why oat-field pea intercrops are a 
popular choice for annual green manures in organic production (Thiessen Martens et al. 2019).

A universal observation was that intercropping reduced weed biomass at harvest (Table 5 ), supporting earlier studies (Blackshaw et al. 2002; Liebman and Dyck 1993). Weed biomass was reduced $(P<0.05)$ by $35 \%$ and $44 \%$ for the medium and high barley seeding rates compared with the field pea monoculture, respectively (Table 5 ). For oat, the medium seeding rate significantly reduced weed biomass by $36 \%$ compared with the field pea monoculture, and the high oat seeding rate significantly reduced weed biomass by $37 \%, 25 \%$, and $15 \%$, compared with the field pea monoculture, and low and medium oat seeding rates, respectively. Mustard resulted in the least weed suppression; $17 \%$ less weed biomass at the higher mustard seeding rate compared with the field pea monocrop (Table 5). Except for mustard, our levels of weed suppression were similar to the field pea intercropping study of Fernandez et al. (2015) in Minnesota: oilseed radish (39\%), winter rye $(41 \%)$, oat $(42 \%)$, and wheat $(48 \%)$. The differences in aboveground leaf architecture between pea and barley can increase light interception, leading to increased overall nutrient use, reducing the available resources for weeds (Corre-Hellou et al. 2006; Bedoussac and Justes 2010). In the present study, barley and oats emerged sooner than field pea which may have resulted in an earlier canopy closure when compared with the field pea monoculture, giving the intercrop a size advantage over weeds. Barley and oats are competitive against weeds due to rapid biomass production and allelopathic compounds found in their plant residue (Satorre and Snaydon 1992; Grimmer and Masiunas 2005; Bouhaouel et al. 2015).

No significant interaction was observed for either barley or oat weed biomass (Table 5), even though Carman $2020 b$ contained $48 \%$ and 53\% more weed biomass than the other sites-years. The weed community in Carman $2020 b$ was dominated by green foxtail. As a $\mathrm{C}_{4}$ plant, green foxtail can have a competitive advantage over $C_{3}$ species such as pea, oat, barley and mustard, especially under low soil moisture and high temperature conditions (Peterson and Nalewaja 1992; Taylor et al. 2014). However, even under these conditions, the cereal companion crops provided significant weed suppression.

While others have documented mustard's competitiveness against weeds (Blackshaw et al. 2002; Beckie et al. 2008), in the present study, relatively poor weed suppression by mustard, compared with cereals was observed. This may be because flea beetle damage to the mustard crop reduced plant growth to the point where mustard's weed competitiveness declined. Pridham and Entz (2008) found that mustard in an organic wheat-mustard intercrop did not increase net primary productivity owing to flea beetles defoliating the mustard plants.

\section{Grain yield}

Relatively low field pea grain yields (1650 to $2238 \mathrm{~kg} \cdot \mathrm{ha}^{-1}$ ) reflect the water limited conditions of our study. A 2019 survey (Bailey-Elkin 2021) showed organic pea yields grown in intercrops ranged from 1008 to $4033 \mathrm{~kg} \cdot \mathrm{ha}^{-1}$, while unweeded yellow field pea yields over six site-years in Minnesota ranged from 2229 to $3607 \mathrm{~kg} \cdot \mathrm{ha}^{-1}$ (Fernandez et al. 2015).

In addition to below-average precipitation, the low water holding capacity of sandy soils at Carman (Mills and Haluschuk 1993) likely exacerbated the stress. Under these water-limited growing conditions, intercropping consistently resulted in a field pea yield decline (Table 6). For barley, the highest seeding rate reduced field pea yield by $15 \%(P<0.05)$ compared with the field pea monoculture (Table 6). For oats, the low, medium, and high seeding rates reduced $(P<0.05)$ field pea yield by $12 \%, 17 \%$, and $26 \%$, compared with the field pea monoculture, respectively (Table 6). Furthermore, yield was significantly reduced by the high oat seeding rate compared with the low and medium rates. For mustard, the low, medium, and high seeding rates significantly reduced field pea yield by $6 \%, 8 \%$, and $16 \%$, compared with the field pea monoculture, respectively (Table 6).

Working under similar water-limited conditions, Carr et al. (1995) found that intercropping lentil (Lens culinaris) and field pea with other crops was not successful. Under water-limited conditions, below-ground competition for water may increase as the different crop species begin to share similar areas of the soil profile (similar resource pool), resulting in greater niche overlap (Bramley et al. 2007), limiting some intercropping benefits. Interestingly, Fernandez et al. (2015) found that competition between intercrops (and weeds) and field pea were reduced even when soil moisture levels were adequate. On the other hand, other researchers have observed positive benefits to grain intercropping (Saucke and Ackermann 2006). Hauggaard-Nielsen et al. (2001) and Sekiya and Yano (2004) reported that under adequate soil moisture, different root growth habits among crop species can lead to water being used from different areas of the soil profile, thereby resulting in less competition between crop species.

In grain intercropping, as one crop species density is increased over another with similar environmental niche requirements, the level of interspecific competition increases, resulting in reduced biomass and grain yields of the crop species that is being outcompeted (Vandermeer 1992; Pelzer et al. 2016). Therefore, when designing intercropping systems, the unique environmental niche of each crop partner must be considered. Field peas have a shallow root system with the majority of the root biomass within approximately $0.6 \mathrm{~m}$ of the soil surface (Cutforth et al. 2013). Mustard has a tap-root structure ( 0.3 to $1 \mathrm{~m}$ length) which centralizes the majority of the root biomass in one area (Province of Ontario 2016a). In comparison, oats and barley have deep fibrous 
Table 6. Mean grain yields, pea protein, and pea thousand kernel weight (TKW) of three pea intercrop (IC) experiments (pea-barley, pea-oat, and pea-mustard), averaged across three site-years in 2019 and 2020, in Carman MB, Canada.

\begin{tabular}{|c|c|c|c|c|c|c|c|c|c|c|c|c|}
\hline \multirow[b]{3}{*}{ Site-year } & \multicolumn{4}{|c|}{ Pea-Barley } & \multicolumn{4}{|l|}{ Pea-Oat } & \multicolumn{4}{|c|}{ Pea-Mustard } \\
\hline & \multicolumn{2}{|c|}{ Grain yield $^{a}$} & \multirow[t]{2}{*}{$\mathrm{TKW}^{b}$} & \multirow[t]{2}{*}{ Protein $^{c}$} & \multicolumn{2}{|c|}{ Grain yield } & \multirow[t]{2}{*}{ TKW } & \multirow[t]{2}{*}{ Protein } & \multicolumn{2}{|c|}{ Grain yield } & \multirow[t]{2}{*}{ TKW } & \multirow[t]{2}{*}{ Protein } \\
\hline & Pea & Barley & & & Pea & Oat & & & Pea & Mustard & & \\
\hline Carman 2019 & $1949 b^{a}$ & $1012 \mathrm{a}$ & $247.8 \mathrm{a}$ & $24.0 \mathrm{a}$ & $1838 b$ & $962 a$ & $244.6 a$ & $23.7 \mathrm{a}$ & $2124 b$ & $74 a$ & $236.5 a$ & $23.5 b$ \\
\hline Carman $2020 a$ & $2867 a$ & $30 c$ & $229.9 b$ & $24.0 \mathrm{a}$ & 2921a & $28 \mathrm{c}$ & $232.1 b$ & $24.2 \mathrm{a}$ & $2727 a$ & $27 \mathrm{~b}$ & $234.8 \mathrm{a}$ & 24.3a \\
\hline Carman 2020b & $1063 c$ & $120 \mathrm{~b}$ & $220.2 b$ & $23.6 \mathrm{a}$ & $1034 \mathrm{c}$ & $398 b$ & $220.2 c$ & $23.7 \mathrm{a}$ & $1034 \mathrm{c}$ & $43 \mathrm{~b}$ & $209.3 b$ & 24.2ab \\
\hline \multicolumn{13}{|l|}{ Treatment } \\
\hline Pea monocrop & 2129a & - & $230.5 b$ & $23.8 \mathrm{a}$ & $2238 a$ & - & $229.2 b$ & $23.8 \mathrm{a}$ & $2125 a$ & - & $220.4 a$ & 23.9a \\
\hline IC low seed rate & 1984ab & $78 c$ & 231.0ab & $23.8 \mathrm{a}$ & 1970b & $151 c$ & 231.6ab & $23.7 \mathrm{a}$ & 1990b & $19 c$ & 227.9a & 23.9a \\
\hline IC medium seed rate & 1924ab & $141 b$ & 232.0ab & $23.8 \mathrm{a}$ & $1866 b$ & $212 b$ & $229.6 b$ & 23.9a & $1954 b$ & $55 b$ & $227.0 \mathrm{a}$ & $24.2 \mathrm{a}$ \\
\hline IC high seed rate & $1801 b$ & $320 a$ & $237.0 \mathrm{~b}$ & $24.0 \mathrm{a}$ & $1650 c$ & $328 a$ & $238.8 \mathrm{a}$ & 24.1a & $1776 \mathrm{c}$ & $83 a$ & 232.1a & 24.1a \\
\hline Site-year effect & $<0.0001$ & $<0.0001$ & 0.0005 & 0.1074 & $<0.0001$ & $<0.0001$ & 0.0016 & 0.1201 & $<0.0001$ & 0.0010 & 0.0015 & 0.0191 \\
\hline Treatment effect & 0.0032 & $<0.0001$ & 0.0350 & 0.7745 & $<0.0001$ & $<0.0001$ & 0.0283 & 0.1105 & $<0.0001$ & $<0.0001$ & 0.2631 & 0.2473 \\
\hline $\begin{array}{l}\text { Site-year } \times \text { treatment } \\
\text { interaction }\end{array}$ & 0.0002 & 0.0040 & 0.1432 & 0.2226 & $<0.0001$ & 0.7452 & 0.6270 & 0.0854 & 0.0347 & 0.1764 & 0.2104 & 0.1795 \\
\hline
\end{tabular}

Note: Means with different letters in the same column are significantly different (Tukey's HSD, $P<0.05$ ).

${ }^{a}$ Grain yields reported in $\mathrm{kg} \cdot \mathrm{ha}^{-1}$.

${ }^{b}$ Pea seed thousand kernel weights.

${ }^{c}$ Pea seed protein percentage on a dry matter basis. 
root structures that can reach depths of 0.84 to $1.95 \mathrm{~m}$ and 1.8 to $2.1 \mathrm{~m}$, respectively (Province of Ontario 2016b, 2016c). While our study included different companion crops in an effort to provide contrasting herbage (eg., grass verses broadleaved) and root (eg., fibrous rooted cereals; taprooted brassica) structures aimed at utilizing different niches (Fernandez et al. 2015), all companion crops reduced field pea yield. The challenge is even greater in organic production where a third plant partner must be considered, weeds. The type of niche occupied by the "weed intercrop partner" in organic cropping systems will be based on the weed community present. Future research should consider detailed resource pool use (Smith et al. 2010) for intercrops of organic field peas with various partner species, including both crops and weeds.

Site-year by intercrop seeding rate interactions were observed in all three experiments (Table 6); the field pea yield reduction with intercrop seeding rate was more serious in 2019 than in $2020 a$ or $2020 b$ (e.g., barley, Fig. 1B). One explanation for a great negative effect on seeding rates in 2019 was the accidental doubling of the seeding rate that year. The conclusion, certainly for barley, was that at the planned seeding rates, barley did not affect field pea yield; negative effects were only observed at much higher rates. Increasing the seeding rate of barley and oats is known to increase grain yield and the competitiveness with other plants (Blackshaw et al. 2002; Mason et al. 2007; Beres et al. 2010). One reason for greater competitiveness of field pea in Carman $2020 a$ was lower soil N (12.5 ppm, 0-30 cm) (Table 1). Carkner and Entz (2017) observed that organic soybeans were most competitive with weeds when soil $\mathrm{N}$ status at planting was low. In Carman 2020b, where soil N levels were similar to Carman 2020a, the high level of green foxtail may have outcompeted field pea. Furthermore, pea yield results in the present study also corresponded to those of Boerboom and Young (1995) and SantínMontanyá et al. (2014) whereby field pea yields were found to be reduced by low precipitation and high weed populations. Boerboom and Young (1995) experienced growing conditions that were similar to the low precipitation in June in the Carman 2019 site-year (Table 3), and the high levels of weeds found in the Carman $2020 b$ site-year.

For mustard, there were significant reductions in field pea yield in both 2019 and 2020a, even though no seeding rate error occurred (Fig. 1C). One explanation may have been the much greater weed competition in Carman 2020b; at high plant densities green foxtail is known to be highly competitive (Weaver 2001) and may have masked any negative effects of the mustard. Our results contrast with Langat (1992) who found no negative effect of mustard intercrops on field pea yields. Similar to observations by Pridham and Entz (2008), mustard in the present study was attacked by later season flea beetles. The late season defoliation by insects sometimes resulted in the unfortunate scenario where the companion crop (in this case mustard) exerted a negative effect on the main crop (field peas) but yielded poorly due to seed pod defoliation. By comparison, barley and oat were not affected by any late-season insect or pathogen attacks.

The average field pea protein percentage on a dry matter basis was $23.9 \%$, and the presence of intercrops did not change field pea grain protein content (Table 6). The average field pea seed mass was $230.6 \mathrm{~g}$, and results showed that field pea seed mass was significantly greater for the highest oat seeding rate compared with the other seeding rates of the field pea monocrop (Table 6). Langat (1992) studied field pea-mustard intercrops and found that the thousand kernel weight of field peas were higher in intercrop treatments, when compared with field pea monocrop treatments. Langat (1992) attributed this response to competition stress within the intercrops resulting in a low number of pods per plant, but greater supply of photosynthates per pod, resulting in greater individual seed mass.

\section{Synthesis of the weed-crop trade-off}

Given that intercropping resulted in both reduced weed growth and a reduced field pea grain yield, an important question regards the level of field pea yield loss sustained per unit of weed suppression with the intercrops. In other words, how much pea yield did the weed control cost? Expressed as $\mathrm{kg}$ of weed biomass reduction per $\mathrm{kg}$ of field pea yield loss at the highest seeding rate for intercrops, mustard averaged 0.87 , oat averaged 1.29, and barley averaged 2.62. Therefore, barley provided the highest level of weed suppression at the lowest field pea yield cost.

The seed cost for the high seeding rate barley, mustard, and oat treatments were $\$ 27.31 \mathrm{ha}^{-1}$, \$75.67 ha ${ }^{-1}$, and $\$ 32.63 \mathrm{ha}^{-1}$, respectively (Table 2). These companion crop seed costs can be considered the price of weed management. By comparison, Alba (2019) found that the cost of using a rotary hoe, harrow, or interrow cultivator for weed control in organic field pea production was $\$ 47.20 \mathrm{ha}^{-1}, \$ 30.00 \mathrm{ha}^{-1}$, and $\$ 34.00 \mathrm{ha}^{-1}$, respectively.

\section{Economic analysis}

Based on the costs of production and a field pea market price of $\$ 0.53$ per $\mathrm{kg}$, field pea monoculture grain yield needed to exceed $2208 \mathrm{~kg} \cdot \mathrm{ha}^{-1}$ for a positive net return. Site-year was the most consistent effect with Carman 2019 and 2020a registering positive net returns and Carman 2020b showing a negative net return (Table 7).

Significant interactions were observed for net return in field pea-oat and field pea-mustard intercrops (Table 7). For field pea-mustard, the significant interaction was attributed to a greater magnitude of net return decline with increasing mustard seeding rate at Carman 
Table 7. Mean net returns of three pea intercrop (IC) experiments (pea-barley, pea-oat, and pea-mustard), averaged across three siteyears in 2019 and 2020, in Carman MB, Canada.

\begin{tabular}{llll}
\hline & \multicolumn{2}{l}{$\$$ ha $^{-1}$} & \\
\cline { 2 - 4 } & Pea-Barley & Pea-Oat & Pea-Mustard \\
\hline Site-year & & & \\
$\quad$ Carman 2019 & $154.54 \mathrm{a}$ & $182.88 \mathrm{a}$ & $55.23 \mathrm{~b}$ \\
$\quad$ Carman 2020a & $361.75 \mathrm{a}$ & $387.58 \mathrm{a}$ & $297.91 \mathrm{a}$ \\
Carman 2020b & $(555.77) \mathrm{b}^{a}$ & $(462.15) \mathrm{b}$ & $(585.87) \mathrm{c}$ \\
\hline Treatment & & & \\
Pea monocrop & $(24.43) \mathrm{a}$ & $15.91 \mathrm{a}$ & $(44.11) \mathrm{a}$ \\
IC low seed rate & $(32.54) \mathrm{a}$ & $41.59 \mathrm{a}$ & $(84.22) \mathrm{ab}$ \\
IC medium seed rate & $(2.58) \mathrm{a}$ & $49.30 \mathrm{a}$ & $(52.80) \mathrm{a}$ \\
IC high seed rate & $(6.92) \mathrm{a}$ & $37.61 \mathrm{a}$ & $(129.19) \mathrm{b}$ \\
\hline Site-year Effect & $<0.0001$ & $<0.0001$ & $<0.0001$ \\
$\quad$ Treatment Effect & 0.6998 & 0.7372 & 0.0053 \\
Site-year*treatment & 0.5488 & 0.0001 & 0.0008 \\
Interaction & & & \\
\hline
\end{tabular}

Note: Means with different letters in the same column are significantly different (Tukey's HSD, $P<0.05$ ).

${ }^{a}$ Parentheses indicate negative values.

$2020 a$ compared with the other site-years (Data not shown). Therefore, adding mustard to a full seeding rate of field pea decreased net return in all cases, though sometimes the negative effect was less severe than others. The presence of flea beetles appeared to play a significant role in the results since mustard biomass competed with field pea plants but, the mustard plants themselves produced little seed yield (Table 6).

For field pea-oat, the site-year interaction showed that intercropping with the high oat seeding rate improved net return at Carman $2020 b$ but significantly reduced net return at Carman $2020 a$ (Fig. 1D). By comparison, oat intercropping did not affect net return in 2019. Improved net returns with intercropping at Carman $2020 b$ may be attributed to weedier conditions, which oats helped to control. Under less weedy conditions at Carman 2020a, on the other hand, the presence of the oat intercrop significantly reduced net return compared with field pea monoculture (Fig. 1D). Oat was the only companion crop to show any improvement in net return and this was only observed at one site-year characterized by late seeding and weedy conditions.

Our results support those of (Fernandez et al. 2015) who also observed few economic benefits of field pea intercrops. When using a field pea market price that was $46 \%$ greater than ours, Fernandez et al. (2015) found that field pea-oat intercrops were the least profitable (\$1498 ha ${ }^{-1}$ ) of five different field pea intercrop mixtures studied, with net returns that were $45 \%$ less profitable than the unweeded field pea monoculture control. Fernandez et al. (2015) found no difference in profitability between a field pea-oilseed radish intercrop and unweeded field pea monoculture control. Although field pea yields were reduced by the presence of oilseed radish, they attributed the high net returns to the high market price for oilseed radish seed $\left(\$ 3.31 \mathrm{~kg}^{-1}\right)$.

\section{Summary and Conclusions}

Our study supported previous research (eg., Bedoussac and Justes 2010; Corre-Hellou et al. 2011; Fernandez et al. 2015) where field pea intercropping provided significant weed control benefits, and that intercrops did not significantly interfere with field pea establishment. We measured the trade-off between weed suppression and field pea yield loss and found that barley was the most efficient weed suppressing companion crop.

In most cases, intercropping did not improve shortterm economic outcomes as measured by net return to the farmer; results showed both significant increases and decreases in net return with seeding rate depending on growing circumstances. We concluded that field pea monoculture yields needed to exceed $2208 \mathrm{~kg} \cdot \mathrm{ha}^{-1}$ for a positive net return, and early seeding was important to achieving this yield goal. Only under conditions of later seeding and high weed pressure did field peaoat intercrops significantly increased net returns over field pea monoculture. Additional research is required to better understand the conditions which might lend themselves to more positive intercropping outcomes, including conducting additive design organic intercropping experiments in wetter growing conditions. Furthermore, this study was limited because the three site-years were in the same location. Future intercrop studies should be implemented across different regions 
to understand how field pea intercrops function across different growing regions. It is also important to note that our work did not consider the role of intercropping on future weed challenges. The significant reduction in weed biomass recorded here should translate into longer term weed management benefits to organic producers.

No weed management factors other than intercropping were considered in our study. Future studies should test intercrops in the presence of supplemental weed management tools such as increased field pea seeding rate (Baird et al. 2009) and mechanical weed control (Alba 2019). Further, the role of different intercrop and even field pea genotypes should be tested to better understand the role that genetic variation might play in the intercrop plant community.

While intercrops did produce their own grain yields, with barley producing the most, the lower economic value of intercrops compared with field pea limited the economic success of the intercrop in our work. More valuable companion crops should be explored in future research. The experience with insect damage to the mustard intercrops tested here, should alert future researchers to be mindful of pest resistance of future intercrop candidates.

\section{Acknowledgements}

We gratefully acknowledge the technical assistance of Katherine Stanley and Wilson Fink. This research was supported by The Manitoba Pulse and Soybean Growers Association and the Manitoba Government. Scholarships to the senior author included: the Lord Selkirk Association of Rupert's Land Agriculture Scholarship, the W.W. Thomson Scholarship, the William Wilson Muir Graduate Fellowship, the University of Manitoba Graduate Fellowship, the Prairie Improvement Network Graduate Fellowship, and the OCIA Research and Education Scholarship.

\section{References}

Alba, O.S. 2019. Integrating the organic arsenal for weed control in field pea and lentil (Thesis). University of Saskatchewan.

Anderson, R. 2005. A multi-tactic approach to manage weed population dynamics in crop rotations. Agron. J. 97: 1579-1583. doi:10.2134/agronj2005.0194.

Anil, L., Park, J., Phipps, R.H., and Miller. 1998. Temperate intercropping of cereals for forage: a review of the potential for growth and utilization with particular reference to the UK. Grass Forage Sci. 53: 301-317. doi:10.1046/j.1365-2494.1998. 00144.x.

Arlauskiene, A., Sarunaite, L., Kadziuliene, Z., Deveikyte, I., and Maiksteniene, S. 2014. Suppression of annual weeds in pea and cereal intercrops. Agron. J. 106: 1765-1774.

Bailey-Elkin, W., 2021. Intercropping studies in organic pea production. M.Sc, thesis, Department of Plant Science, University of Manitoba.

Baird, J.M., Walley, F.L., and Shirtliffe, S.J. 2009. Optimal seeding rate for organic production of field pea in the northern Great Plains. Can. J. Plant Sci. 89: 455-464. doi:10.4141/ CJPS08113.
Beckie, H.J., and Brandt, S.A. 1997. Nitrogen contribution of field pea in annual cropping systems. 1. Nitrogen residual effect. Can. J. Plant Sci. 77: 311-322. doi:10.4141/P96-161.

Beckie, H.J., Johnson, E.N., Blackshaw, R.E., and Gan, Y. 2008. Productivity and quality of canola and mustard cultivars under weed competition. Can. J. Plant Sci. 88: 367-372. doi:10.4141/CJPS07152.

Bedoussac, L., and Justes, E. 2010. Dynamic analysis of competition and complementarity for light and $\mathrm{N}$ use to understand the yield and the protein content of a durum wheat-winter pea intercrop. Plant Soil. 330: 37-54. doi:10.1007/s11104-0100303-8.

Beres, B.L., Harker, K.N., Clayton, G.W., Bremer, E., Blackshaw, R.E., and Graf, R.J. 2010. Weed-competitive ability of spring and winter cereals in the northern great plains. Weed Technol. 24: 108-116.

Bitew, Y., Alemayehu, G., Adgo, E., and Assefa, A. 2020. Competition, production efficiency and yield stability of finger millet and legume additive design intercropping. Renew. Agric. Food Syst., 1-12. doi:10.1017/S1742170520000101.

Blackshaw, R.E., O’donovan, J.T., Harker, K.N., and Li, X. 2002. Beyond herbicides: New approaches to managing weeds. Presented at the ICESA.

Boerboom, C., and Young, F. 1995. Effect of postplant tillage and crop density on broadleaf weed control in dry pea (pisum sativum) and lentil (lens culinaris). Weed Technol. 9: 99-106. doi:10.1017/S0890037X00023022.

Borstlap, S., and Entz, M.H. 1994. Zero-tillage influence on canola, field pea and wheat in a dry subhumid region: Agronomic and physiological responses. Can. J. Plant Sci. 74: 411-420. doi:10.4141/cjps94-078.

Bouhaouel, I., Bouhaouel, I., Gfeller, A., Gfeller, A., Fauconnier, M.-L., Fauconnier, M.-L., et al. 2015. Allelopathic and autotoxicity effects of barley (Hordeum vulgare L. ssp. vulgare) root exudates. BioControl (Dordrecht, Netherlands) 60: 425-436. doi:10.1007/s10526-014-9634-3.

Bramley, H., Turner, D.W., Tyerman, S.D., and Turner, N.C. 2007. Water flow in the roots of crop species: The influence of root structure, aquaporin activity, and waterlogging. Adv. Agron. 96: 133-196. doi:10.1016/S0065-2113(07)96002-2.

Canadian Organic Trade Association. 2018. Organic Agriculture in the Prairies: 2018 Data | Canadian Prairies | Legume.

Carkner, M.K., and Entz, M.H., 2017. Growing environment contributes more to soybean yield than cultivar under organic management. Field Crops Res. 207: 42-51. doi:10.1016/ j.fcr.2017.02.019.

Carr, P.M., Gardner, J.J., Schatz, B.G., Zwinger, S.W., and Guldan, S.J. 1995. Grain yield and weed biomass of a wheat-lentil intercrop. Agron. J. 87: 574-579. doi:10.2134/agronj1995.000 21962008700030030x.

Chapagain, T., and Riseman, A., 2014. Barley-pea intercropping: Effects on land productivity, carbon and nitrogen transformations. Field Crops Res. 166. doi:10.1016/j.fcr.2014.06.014.

Chen, C., Miller, P., Muehlbauer, F., Neill, K., Wichman, D., and McPhee, K. 2006. Winter pea and lentil response to seeding date and micro- and macro-environments. Agron. J. 98: 1655-1663. doi:10.2134/agronj2006.0085.

Corre-Hellou, G., Dibet, A., Hauggaard-Nielsen, H., Crozat, Y., Gooding, M., Ambus, P., et al. 2011. The competitive ability of pea-barley intercrops against weeds and the interactions with crop productivity and soil $\mathrm{N}$ availability. Field Crops Res. 122: 264-272. doi:10.1016/j.fcr.2011.04.004.

Corre-Hellou, G., Fustec, J., and Crozat, Y., 2006. Interspecific competition for soil $\mathrm{N}$ and its interaction with $\mathrm{n} 2$ fixation, leaf expansion and crop growth in Pea-Barley intercrops. Plant Soil 282: 195-208. doi:10.1007/s11104-005-5777-4.

Cutforth, H.W., Angadi, S.V., McConkey, B.G, Miller, P.R., Ulrich, D., Gulden, R., et al. 2013. Comparing rooting characteristics 
and soil water withdrawal patterns of wheat and alternative oilseed and pulse crops grown in the semiarid Canadian prairie. Can J Soil Sci. 93: 147-160.

Fernandez, A., Sheaffer, C., and Wyse, D. 2015. Productivity of field pea and lentil with cereal and brassica intercrops. Agron. J. 107: 249-256. doi:10.2134/agronj14.0361.

Gliessman, S.R., 1990. Understanding the basis of sustainability for agriculture in the tropics: experiences in Latin America. Sustain. Agric. Syst., 378-390.

Government of Saskatchewan, 2020. Crop Planning Guide and Crop Planner | Saskatchewan Farm Business Management. Government of Saskatchewan.

Grimmer, O.P., and Masiunas, J.B., 2005. The weed control potential of oat cultivars. HortTechnology (Alexandria, Va.) 15: 140-144. doi:10.21273/HORTTECH.15.1.0140.

Harker, K.N., 2001. Survey of yield losses due to weeds in central Alberta. Can. J. Plant Sci. 81: 339-342. doi:10.4141/P00-102.

Hauggaard-Nielsen, H., Ambus, P., and Jensen, E.S. 2001. Temporal and spatial distribution of roots and competition for nitrogen in pea-barley intercrops - A field study employing 32P technique. Plant Soil 236: 63-74. doi:10.1023/A: 1011909414400.

Hauggaard-Nielsen, H., Gooding, M., Ambus, P., Corre-Hellou, G., Crozat, Y., Dahlmann, C., et al. 2009. Pea-barley intercropping for efficient symbiotic N2-fixation, soil $\mathrm{N}$ acquisition and use of other nutrients in European organic cropping systems. Field Crops Res. 113: 64-71. doi:10.1016/ j.fcr.2009.04.009.

Izaurralde, R., McGill, W., and Juma, N. 1992. Nitrogen fixation efficiency, interspecies $\mathrm{N}$ transfer, and root growth in barley-field pea intercrop on a Black Chernozemic soil. Biol. Fert. Soils 13: 11-16. doi:10.1007/BF00337231.

Jiang, Y., Davis, A.R., Vujanovic, V., and Bueckert, R.A. 2019. Reproductive development response to high daytime temperature in field pea. J. Agron. Crop Sci. (1986) 205: 324-333. doi:10.1111/jac.12328.

Juskiw, P.E., and Helm, J.H. 2003. Barley response to seeding date in central Alberta. Can. J. Plant Sci. 83: 275-281. doi:10.4141/P02-049.

Langat, P.K. 1992. Effect of intercropping pea with canola or yellow mustard. Thesis MSc-University of Manitoba, Fall 1992.

Liebman, M., and Dyck, E. 1993. Crop rotation and intercropping strategies for weed management. Ecolog. Appl. 3: 92-122. doi:10.2307/1941795.

Ma, B.-L. 2016. Crop rotations: farming practices, monitoring and environmental benefits, Agriculture Issues and Policies. Nova Publishers, New York, [New York].

Manitoba Pulse \& Soybean Growers. 2019. Roquette Canada Ltd.: The Yellow Pea Era Begins. [Online]. Available from https:// www.manitobapulse.ca/2019/06/roquette-canada-ltd-theyellow-pea-era-begins-in-manitoba/.

Manitoba Agricultural Services Corporation. 2020. MASC Agrilnsurance Programs.

Manitoba Agriculture and Resource Development. 2020. Interpretive Soil Maps. Province of Manitoba - Agriculture.

Martin-Guay, M.-O., Paquette, A., Dupras, J., and Rivest, D. 2018. The new Green Revolution: Sustainable intensification of agriculture by intercropping. Sci. Total Environ. 615: 767-772. doi:10.1016/j.scitotenv.2017.10.024.

Mason, H., Navabi, A., Frick, B., O’Donovan, J., and Spaner, D. 2007. Cultivar and seeding rate effects on the competitive ability of spring cereals grown under organic production in Northern Canada. Agron. J. 99: 1199-1207. doi:10.2134/ agronj2006.0262.

Mills, G.F., and Haluschuk, P. 1993. CANADA-MANITOBA Soil Survey: Soils of the Carman Research Station.
Monti, M., Pellicanò, A., Santonoceto, C., Preiti, G., and Pristeri, A. 2016. Yield components and nitrogen use in cereal-pea intercrops in Mediterranean environment. Field Crops Res. 196: 379-388. doi:10.1016/j.fcr.2016.07.017.

Nelson, A.G., Pswarayi, A., Quideau, S., Frick, B., and Spaner, D. 2012. Yield and weed suppression of crop mixtures in organic and conventional systems of the Western Canadian Prairie. Agron. J. 104: 756-762. doi:10.2134/agronj2011.0374.

OrganicBiz. 2020. Organic price quotes: Late December. OrganicBiz.

Patra, D.D., Sachdev, M.S., and Subbiah, B.V.1986. 15N studies on the transfer of legume-fixed nitrogen to associated cereals in intercropping systems. Biol. Fert. Soils 2: 165-171. doi:10.1007/BF00257596.

Pelzer, E., Bazot, M., Guichard, L., and Jeuffroy, M.-H. 2016. Crop management affects the performance of a winter peawheat intercrop. Agron. J. 108: 1089-1100. doi:10.2134/ agronj2015.0440.

Peterson, D.E., and Nalewaja, J.D. 1992. Environment Influences Green Foxtail (Setaria viridis) Competition with Wheat (Triticum aestivum). Weed Technol. 6: 607-610.

Podgórska-Lesiak, M., and Sobkowicz, P. 2013. Prevention of pea lodging by intercropping barley with peas at different nitrogen fertilization levels. Field Crops Res. 149: 95-104. doi:10.1016/j.fcr.2013.04.023.

Pridham, J., and Entz, M. 2008. Intercropping spring wheat with cereal grains, legumes, and oilseeds fails to improve productivity under organic management. Agron. J. 100: 1436-1442. doi:10.2134/agronj2007.0227.

Pridham, J.C. 2006. The effect of intercropping systems and cultivar mixtures on weed and disease suppression in organically managed spring wheat (Masters). University of Manitoba.

Province of Manitoba. 2020. Guidelines for Estimating Organic Crop Production Costs. Province of Manitoba - Agriculture. [Online]. Available from https://www.gov.mb.ca/agriculture/ farm-management/production-economics/pubs/cop-croporganic-production.pdf.

Province of Ontario. 2016a. Cover Crops: Other Brassicas. [Online]. Available from http://www.omafra.gov.on.ca/ english/crops/facts/cover_crops01/other_brassicas.htm.

Province of Ontario. 2016b. Cover Crops: Barley. [Online.] Available from http://www.omafra.gov.on.ca/english/crops/ facts/cover_crops01/barley.htm.

Province of Ontario. 2016c. Cover Crops: Oats. [Online.] Available from http://www.omafra.gov.on.ca/english/crops/ facts/cover_crops01/oats.htm.

Santín-Montanyá, M.I., Zambrana, E., Fernández-Getino, A.P., and Tenorio, J.L. 2014. Dry pea (Pisum sativum L.) yielding and weed infestation response, under different tillage conditions. Crop Protect. 65: 122-128. doi:10.1016/j.cropro. 2014.07.017.

SAS Institute, Inc. 2020. SAS/STAT MIXED Procedure.

Saskatchewan Crop Insurance Corporation. 2020. Saskatchewan Crop Insurance Corporation - Base Prices. SCIC.

Satorre, E.H., and Snaydon, R.W.1992. A comparison of root and shoot competition between spring cereals and Avena fatua L. Weed Res. 32: 45-55. doi:10.1111/j.1365-3180.1992.tb01861.x.

Saucke, H., and Ackermann, K. 2006. Weed suppression in mixed cropped grain peas and false flax (Camelina sativa). Weed Res. 46: 453-461. doi:10.1111/j.1365-3180.2006.00530.x.

Sekiya, N., and Yano, K. 2004. Do pigeon pea and sesbania supply groundwater to intercropped maize through hydraulic lift?-Hydrogen stable isotope investigation of xylem waters. Field Crops Res. 86: 167-173. doi:10.1016/j.fcr.2003.08.007.

Smith, R.G., Mortensen, D.A., and Ryan, M.R. 2010. A new hypothesis for the functional role of diversity in 
mediating resource pools and weed-crop competition in agroecosystems. Weed Res. 50: 37-48. doi:10.1111/j.13653180.2009.00745.x.

Spies, J.M., Warkentin, T., and Shirtliffe, S. 2010. Basal branching in field pea cultivars and yield-density relationships. Can. J. Plant Sci. 90: 679-690. doi:10.4141/CJPS09195.

Taylor, S.H., Ripley, B.S., Martin, T., De-Wet, L.-A., Woodward, F.I., and Osborne, C.P. 2014. Physiological advantages of C4 grasses in the field: A comparative experiment demonstrating the importance of drought. Global Change Biol. 20: 1992-2003. doi:10.1111/gcb.12498.

Thiessen Martens, J.R., Lynch, D.H., and Entz, M.H. 2019. A survey of green manure productivity on dryland organic grain farms in the eastern prairie region of Canada. Can. J. Plant Sci. 99: 772-776. doi:10.1139/cjps-2018-0311.
Vandermeer, J.H., 1992. The Ecology of Intercropping. Cambridge University Press.

Wall, G.J., Pringle, E.A., and Sheard, R.W. 1991. Intercropping red clover with silage corn for soil erosion control. Can. J. Soil. Sci. 71: 137-145. doi:10.4141/cjss91-013.

Wallace, J., and Canadian Organic Growers. 2001. Organic field crop handbook: a project of Canadian Organic Growers Inc., 2nd ed. Canadian Organic Growers, Ottawa, ON.

Watson, C., Reckling, M., Preissel, S., Bachinger, J., Bergkvist, G., Kuhlman, T., et al. 2017. Grain legume production and use in european agricultural systems. Adv. Agron. 144: 235-303. doi:10.1016/bs.agron.2017.03.003.

Weaver, S.E. 2001. Impact of lamb's-quarters, common ragweed and green foxtail on yield of corn and soybean in Ontario. Can. J. Plant Sci. 81: 821-828. doi:10.4141/P01-057. 